\title{
30. MORPHOLOGICAL INVESTIGATIONS ON THE GENUS GLOBOROTALIA FROM SITE 372
}

\author{
Germaine Bizon, Bureau d'Etudes Industrielles et de Coopération de l'Institut Français du Pétrole, Rueil- \\ Malmaison, France \\ and \\ Georgette Glaçon, Département de Géologie structurale, Université de Paris VI, France
}

\begin{abstract}
Several biostratigraphic intervals are distinguished in the Miocene of the Western Mediterranean temperate area (DSDP, Site 372, East Menorca Rise, Balearic Basin).

Evolutionary trends in the Globorotalia scitula praescitula, Globorotalia archeomenardii, Globorotalia praemenardii, and Globorotalia menardii plexus from Langhian to early Tortonian are used in an attempt to define biostratigraphic intervals. Characteristics of the penultimate chamber and carinal development are analyzed. Evolution of thick-walled forms shows the same trends as in thinwalled forms. Broad scale correlations with tropical sequences are recognized.

Several morphotypes seem to be restricted to temperate areas. One new species (Globorotalia magnifica) is described and illustrated.
\end{abstract}

\section{INTRODUCTION}

Morphological investigations were undertaken on various species of Globorotalia found at Site 372, from the Langhian to the late Serravallian-early Tortonian. Evolutionary trends in the Globorotalia scitula praescitula, Globorotalia archeomenardii, Globorotolia praemenardii, Globorotalia menardii and Globorotalia miozea lineages were examined.

This study was made to determine more precisely the biochronology of the middle Miocene, in a temperate region in the western Mediterranean, where only two main events-the extinction of Globorotalia fohsi peripheroronda and the extinction of Globorotalia gr. mayeri-siakensis are observed above the first occurrence of Orbulina suturalis.

The local disappearance of Globigerinoides subquadratus which in tropical areas occurs in the range of the Globorotalia mayeri-siakensis Zone (Bolli, 1966; Stainforth et al., 1975) was not recognized as a datum level in the Mediterranean area because this species is present up to the Globorotalia acostaensis Zone at Site 372 , together with intermediate specimens between Globigerinoides obliquus and G. subquadratus. Blow (1969, p. 246) wrote "The absence of the distinctive subquadratus-ruber morphotypes in any rich assemblage of Globigerinoides ssp. may be used, though with caution, to recognize the interval of uppermost Zone N 13 to lowermost Zone N 16 when a preliminary provisional assessment is being made of post Zone $\mathbf{N}$ 13 assemblages and when other, more direct evidence is absent."
Local disappearance of taxa from part of their total stratigraphic range has occurred frequently in the stratigraphic record. At Site 372, in the interval from Core 18 to Core 10, Globigerinoides subquadratus is not continuously represented (Bizon, range-chart, this volume) and, for example, is not present in Core 17. The same is true for Globigerinoides obliquus over various intervals. The meaning of these local absences cannot yet be explained. Several samples were given to C. Grazzini in an attempt to assess the climatic and salinity influences (Grazzini, Isotope Studies, this volume).

In the Italian area, Cati and Borsetti (1968) found Globigerinoides ruber from Langhian to Tortonian; Crescenti (1966) found the same in the MarcheAbruzze area. In New Zealand (Jenkins, 1971), Globigerinoides subquadratus is present sporadically from early Miocene to late Pleistocene. ${ }^{1}$ Its local disappearance in the temperate waters of the Mediterranean ( $N$ 13-N 16) probably is not as evident as in tropical or subtropical waters.

The evolution of the species in the Mediterranean area is not clear. Globigerinoides subquadratus of early Tortonian (stratotype section, Rio Mazzapiedi, levels 1 to 3, Zone N 15, Cita and Blow, 1969) is similar to the G. subquadratus of the Serravallian, with 3-1/2 chambers in the penultimate whorl, and is different from $G$. ruber, which typically has 3 chambers in the penulti-

1 The stratigraphic range of $G$. subquadratus has not been discussed in any of the Mediterranean congresses (1967, 1971, and 1975). 
mate whorl. The same results have been noted in Sicily (Falconara section) in the lower part of the Globorotalia acostaensis Zone.

We were unable to distinguish the two species in our preliminary investigations on the Globorotalia mayerisiakensis assemblages. A similar opinion was reported recently by Stainforth et al. (1975).

The first occurrence of Sphaeroidinellopsis subdehiscens was found in Core 16, Section 6, associated with $S$. seminulina. Because this species is poorly represented at Site 372, the Sphaeroidinellopsis subdehiscens-Globigerina druryi Zone of Blow (N 13) was difficult to determine. We can only say that N 13 is present in Core 16.

Some difficulties also exist in the distinction between Globigerina druryi and Globigerina nepenthes at Site 372. The true Globigerina nepenthes Todd does not seem to occur at Site 372. Individuals of the species are similar to those illustrated by Zachariasse from Crete (1975, pl. 16, fig. 4) and by Bronnimann from the southwestern Pacific (1971, pl. 1, fig. 4).

The last occurrence of Globorotalia praemenardii (Stainforth et al., 1975, p. 79) is within the range of the Globorotalia siakensis Zone (= N 14 Blow). This was also the case at Site 372 . However, some keeled Globorotalia from the early Tortonian stratotype (levels 1 to 3 ) look very primitive without any limbate spiral suture, and were recognized as Globorotalia praemenardii (Cita et al., 1965). They look very similar to some Globorotalia at Site 372, Core 10 (N 15).

Because a preliminary examination of the planktonic foraminiferal assemblages shows significant differences to that of tropical successions, keeled and unkeeled Globorotalia were carefully examined. They are abundant in some intervals at Site 372 , and quite a number of them are similar to tropical species; others are similar to temperate to cool species from New Zealand.

In the species of Globorotalia investigated at Site 372 , the shape of the penultimate chamber, on the spiral side, is of special interest. This method of investigation is not new. R. C. Tjalsma (Guadalquivir Basin in southern Spain, 1971) and W. J. Zachariasse (in Crete, 1975) were able to distinguish taxa by using a single criterion based on the outline of the chambers on the spiral side. To this characteristic, we add observations on the peripheral margin and carinal development.

\section{MATERIAL AND METHODS}

At Site 372, coring was discontinuous from 112 meters (sub-bottom depth; Core 1) to 406.5 meters (Core 30 ) and discontinuous from 416.5 to 885 meters (Cores 31 to 46). Except for Cores 10, 11, and 12, recovery was excellent in the lower two-thirds of the cored interval (Site 372 Report, this volume).

The material investigated comes from Core 31, Section 2 (Langhian) through Core 9 (Tortonian). More than 500 specimens were examined and photographed on the spiral, umbilical, and apertural sides at $\times 100$ and $\times 200$ with a Cambridge and a Cameca scanning electron microscope, respectively. We gave
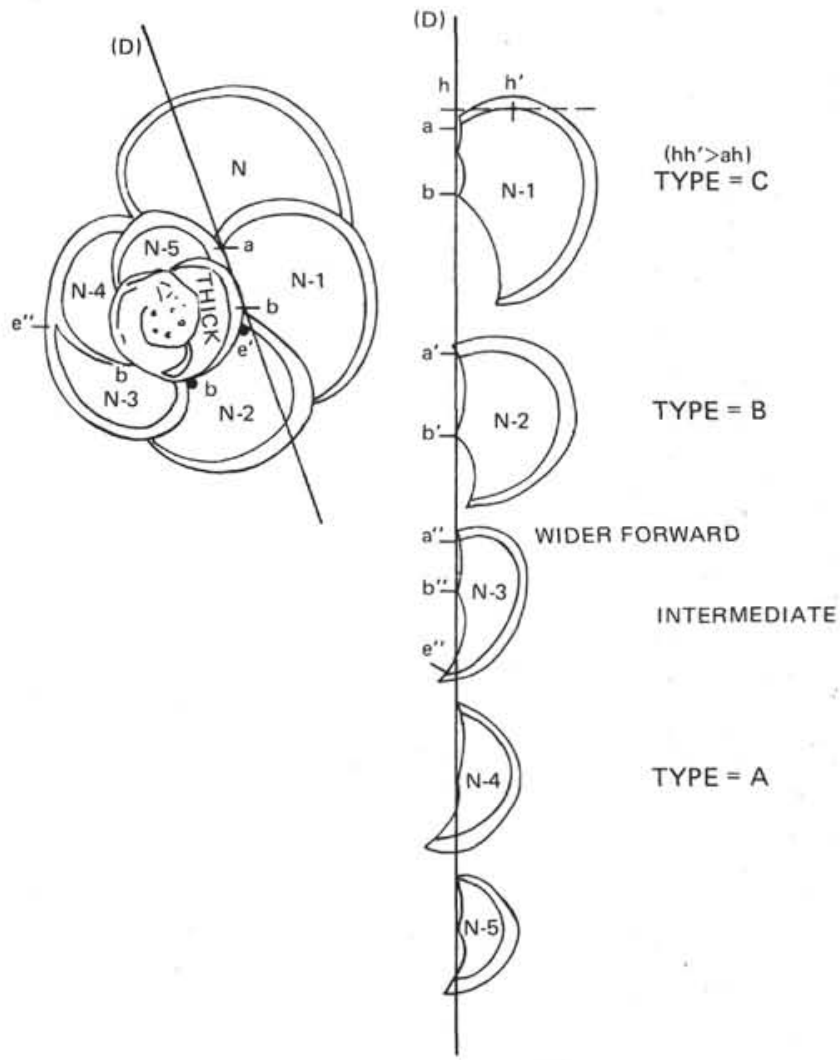

Figure 1. Ontogeny of one Globorotalia, that in Plate 11, Figure 2 (Core 10, Section 1), see text for explanation.

special attention to the internal structure of some thickwalled specimens belonging to the Globorotalia miozea group.

The first investigations were made on the chamber outline of the penultimate chamber on the spiral side. The ultimate chamber was discarded because it is sometimes deformed or incomplete.

We studied the variations in the penultimate chamber to make comparisons with illustrated figures of holotype penultimate chambers from various taxa including Globorotalia scitula praescitula Blow, Globorotalia archeomenardii Bolli, Globorotalia praemenardii Cushman and Stainforth, Globorotalia miozea Finlay (Figure 2), and to make an ontogenetic study of one specimen (Figure 1) wherein a recapitulation of the ancestral characteristics may be seen.

Figure 1 is a graphic representation of the ontogeny of a single specimen. An "advanced type" of Globorotalia (Core 10, Section 1, early Tortonian) is illustrated. A line (D) is drawn from the points $(a, b)$ of the contact of the septal sutures of chambers N/N-1, $\mathrm{N}-1 / \mathrm{N}-2, \ldots$ with the spiral suture. In the earliest chambers (N-5, N-4), a bilateral symmetry is present and the suture between $\mathrm{N}-6 / \mathrm{N}-5$ and $\mathrm{N}-5 / \mathrm{N}-4$ chambers crosses the line D (Type A). In the youngest chambers $(\mathrm{N}-1, \mathrm{~N}-2)$, the suture goes above the line D (Types $\mathrm{B}$ and $\mathrm{C}$ ). Chambers $\mathrm{N}-2$ and $\mathrm{N}-3$ are more rounded (Type B). Chamber N-1 has a forward peripheral outline straighter than Type B and is slightly angular (Type $\mathrm{C}$ ). 

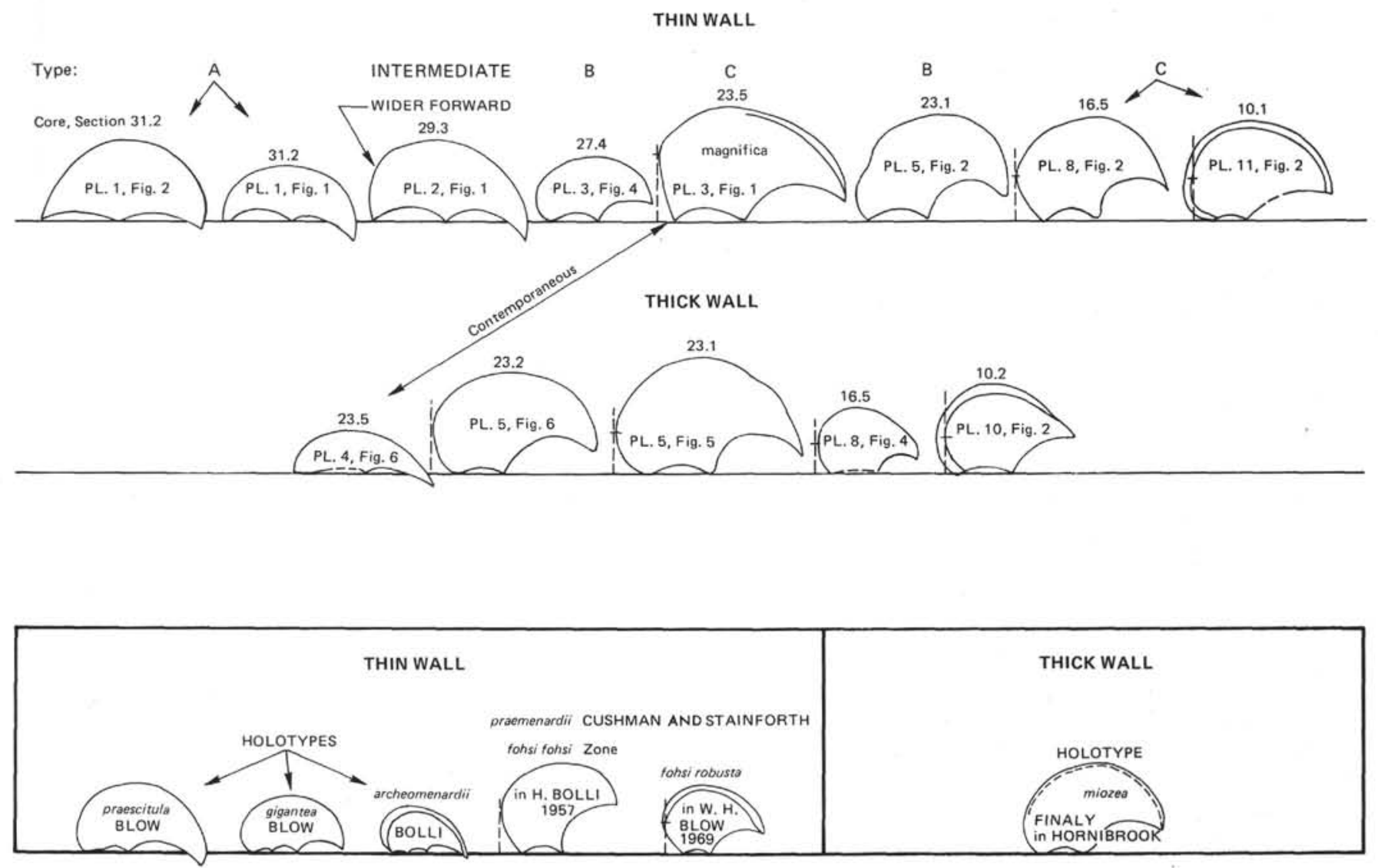

Figure 2. Outline of the penultimate chamber in spiral view (sinistral coiling), see text for explanation.

In Figure 2 (upper part), the outline of the penultimate chamber of some specimens are illustrated from Core 31 to Core 10 . The same three types (Types A, B, and C) observed in the ontogenetic study occur successively from the Langhian to the Tortonian. In the oldest morphotypes (Cores 31, 29), the penultimate chamber has a bilateral symmetry (Type A). The suture between the penultimate chamber and the antepenultimate chamber crosses the line or falls on it. In younger morphotypes (Cores 27 to 10 ), the suture between the penultimate and antepenultimate chamber goes above the line. Distinctions between Types B and $\mathrm{C}$ are made mainly on the forward peripheral outline of the chamber which is rounded in Type B (Cores 27, 23 ), but straighter and somewhat angular in Type C (Cores 16, 10). An initial tendency toward Type $C$ was observed with the first occurrence of Globorotalia magnifica (Core 23, Section 5; Figure 2). A second tendency towards Type C appears later (Core 16, Figure 2) and persists up to Core 9.

Holotype penultimate chamber of Globorotalia scitula praescitula Blow (Figure 2, lower part) belongs to Type A. Specimens of Globorotalia praemenardii from the G. fohsi fohsi Zone belong to Type C: the penultimate chamber is similar to the penultimate chamber of $G$. magnifica. The penultimate chamber of $G$. scitula gigantea Blow and $G$. archeomenardii Bolli is intermediate between Types A and B.

Other successive variables were also observed, more precisely in the carinal development (Figure 3). a) In earlier specimens, a continuous imperforated band is observed on the periphery of the umbilical side G. scitula praescitula, Core 31, Section 2).

b) This continuous imperforated band migrates from the umbilical side towards the margin (Core 23, Section 2).

c) On the spiral side, this imperforated peripheral band is raised, like a rim, but not on the umbilical side (Core 19, Section 5).

d) In younger morphotypes, on the umbilical side, a keel bordered by an imperforated band occurs (Core 10 , Section 2).

Of secondary importance is the dorsal limbation which is present at several intervals.

Thin-walled and thick-walled morphotypes were observed. Scott (1972) noted that thick-walled forms identified as Globorotalia gr. miozea from New Zealand are bathypelagic representatives of thin-walled morphotypes. We have observed the same evolution for the N-1 chamber in both the thick-walled and thinwalled specimens (Figure 2, middle part). Thickwalled morphotypes (A, B, and C) occur generally somewhat later than the thin-walled morphotypes of $\mathrm{A}, \mathrm{B}$, and $\mathrm{C}$.

\section{ILLUSTRATED DESCRIPTION OF THE MORPHOTYPES AND TAXA}

In all samples investigated, a plexus of intergrading variants is observed, but in somewhat different proportions. For example, Type C is present in Core 16, 
G. BIZON, G. GLAÇON

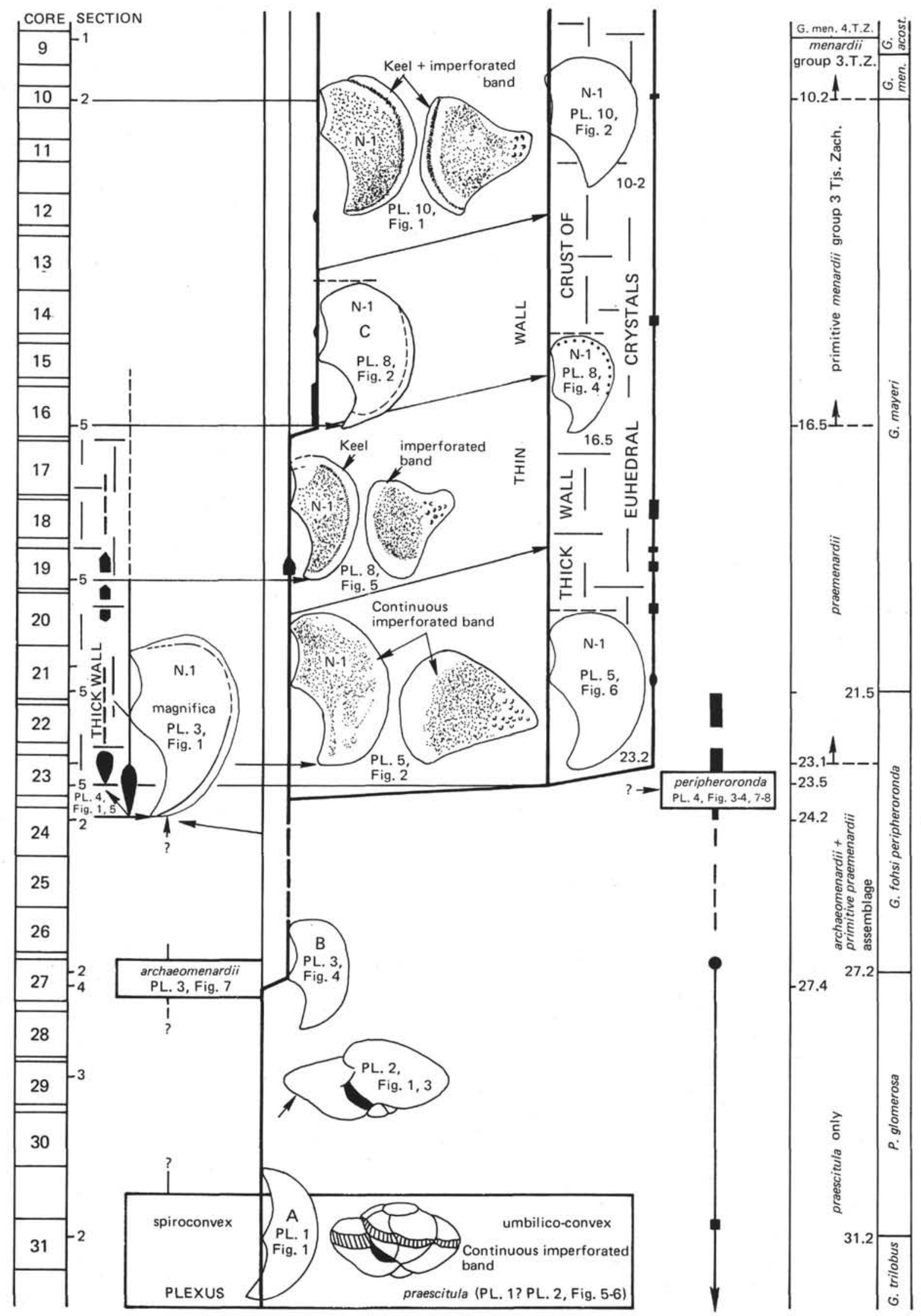

Figure 3. Evolutionary trends on the G. praescitula-menardii plexus - Site 372. 
Section 5, wherein surviving species of Types A and B occur.

Because some of the species, such as G. praemenardii, vary widely in morphology, an open nomenclature has generally been adopted. This approach seems better than using several names that lack true significance.

\section{Core 31, Section 2; Globorotalia scitula praescitula} Plexus (Plate 1, Figures 1-8; Plate 2, Figures 5, 6)

In the spiral view, all of the specimens belong to Type A described above or to an intermediate form between $\mathrm{A}$ and $\mathrm{B}$. The penultimate chamber has a crescent shape with bilateral symmetry, or is wider forward, but always with the suture between chambers $\mathrm{N}-1$ and $\mathrm{N}-2$ crossing the line $\mathrm{a}-\mathrm{b}$ (Figure 1) or falling on it.

Figure 1 in Plate 1 was determined as Globorotalia scitula praescitula Blow. The specimen is smaller than the holotype (diameter $=190 \mu \mathrm{m}$ instead of $300 \mu \mathrm{m}$ for holotype) and has a relatively larger diameter of the penultimate whorl. The umbilicus is closed. In Blow's description, the umbilicus is "often fairly deep." Compared with the photograph of the holotype (Saito and Maiya, 1973), the same kind of porosity is present: larger and fewer pores on the first whorl with a thicker wall, the same peripheral imperforated band on the umbilical face (not seen in the spiral view) and the same aperture. The ideotype illustrated by Blow (1969, pl. 39, fig. 9; Zone N 8, upper part, Barbados, W.I.) is sinistral. The penultimate chamber on the spiral side is of Type B.

Taxa from this horizon have great variability in:

a) the number of chambers in the last whorl, i.e., 4 (Plate 1, Figure 7); 4-1/2 (Plate 1, Figures 2, 6); 5-1/2 (Plate 1, Figure 3); and 6 (Plate 2, Figure 6).

b) shape of test; most of the forms are biconvex, but some are flat on the spiral side (Plate 1, Figure 4) and others are more convex (Plate 1, Figure 7) and are probably ancestors of Globorotalia archeomenardii.

c) the outline of the last chamber; also the periphery of the adult test is more or less lobulate (Plate 1, Figures 4, 8; Plate 2, Figures 5, 6).

d) the imperforated band which is more or less visible, but sometimes not represented (Plate 1, Figure 7).

Of 42 specimens, 6 are dextral and 36 sinistral. Globorotalia fohsi peripheroronda is associated with this plexus.

\section{Core 29, Section 3; Globorotalia scitula praescitula} Plexus-Angular Periphery (Plate 2, Figures 1-4)

In side view, some specimens have an angular peripheral margin (Plate 2, Figures 1,3). The umbilical ultimate chamber wall is slightly concave near the periphery (Plate 2, Figure 1). This feature is also seen in specimens from higher levels. Specimens with a more rounded periphery also occur.
Core 27, Section 4; First Occurrence of Type B (Plate 3, Figures 4-7)

Some spiro-convex specimens were identified as Globorotalia archeomenardii Bolli (Plate 3, Figure 7), but they do not have a true keel or limbate sutures on the spiral side. Other specimens belong also to Type B (Plate 3, Figures 4, 5) and are very similar to Globorotalia praemenardii, but the side-view profile is not so acute, and there is no evidence of an imperforated area on the periphery. They are referred to in this study as "primitive G. praemenardii." The hemispherical outline of the last chamber in some specimens has some analogies with Globorotalia cibaoensis Bermudez (Parker, 1973, pl. 2, fig. 3.), but the morphotype illustrated here (Plate 3, Figure 5) has no keel.

Globorotalia fohsi peripheroronda is not present in Cores 26 and 25 and the lower part of Core 24, but is again abundant in Core 24, Section 2. The same is true for Globorotalia archomenardii (Bizon et al., Range Charts, this volume). The causes of these local absences are not known, but it may be related to an environmental change.

Core 23, Sections 5, 4; Occurrence of Thick-walled Forms and Abundance of Globorotalia magnifica $\mathrm{n}$. sp. (Plate 3, Figures 1-3, Plate 4)

The first occurrence of Globorotalia magnifica n. sp. is in Core 24, Section 2, but they are more abundant in Core 23, Section 5 from where the holotype and paratypes were chosen.

The first occurrence of thick-walled morphotypes was in Core 23, Section 5 (Plate 4, Figure 6). A calcite crust (euhedral layer) has developed on the umbilical side, except on the last two chambers. This specimen looks very similar to Globorotalia miozea Finlay, in Scott (1972, pl. 1, figs. 1-3) where the peripheral imperforated band is clearly seen (umbilical side). This G. miozea looks very primitive and is similar to Globorotalia scitula praescitula: the penultimate chamber is of Type A (Scott, pl. 1, fig. 1).

Globorotalia fohsi peripheroronda occurs commonly in all samples of Core 23. In some specimens, a peripheral umbilical band is clearly seen (Plate 4 , Figure 8).

The specimen illustrated on Plate 4, Figure 2 was not identified. The umbilical peripheral band is clearly seen on side view (Figure $2 b$ ).

Core 23, Sections 2, 1; Occurrence of a Continuous Imperforated Band on the Spiral and Umbilical Side (Plate 5)

The first occurrence of thick-walled forms of Type B occurred in Core 23, Section 2 (Plate 5, Figure 6). This specimen differs from the morphotype illustrated on Plate 4, Figure 6 , by the outline of the penultimate chamber.

In Core 23, Section 1, the imperforated band is displaced from the periphery of the umbilical side to 
the peripheral margin. A continuous imperforated band is clearly seen on the umbilical and spiral views (Plate 5, Figures 2, 5). Globorotalia praemenardii is identified in Figure 2.

In these assemblages, some specimens with an imperforated band on the umbilical margin (Plate 5, Figure 4) are very similar, in spiral view, to Globorotalia peripheroacuta $\mathrm{Blow}$ and Banner. In side view, they are similar to $G$. archeomenardii.

In Plate 5, Figure 3 is a primitive morphotype (penultimate chamber belongs to Type A). Another specimen illustrated in Plate 5, Figure 1 shows a rounded periphery like Globorotalia lenguaensis Bolli. The imperforated band is seen on the umbilical side, as in the Globorotalia scitula praescitula plexus. This is probably one of the ancestors of Globorotalia lenguaensis.

\section{Core 21, Sections 3, 4; Shell-structure of Thick- walled Forms (Plate 6)}

We were able to study the structure of some thickwalled and indeterminable morphotypes on broken specimens. The phases of calcification, accurately described by Bé and Hemleben (1970) for Globigerinoides sacculifer were observed. Only the smooth cortex veneer is missing (compare Plate 6, Figure 1 with fig. 1 of Bé and Hemleben). On Figures 1 and 3, subhedral crystals constrict the pores. The earlier stages are ornamented with spinebases (Figure 4). The juvenile specimens probably lived near the surface waters and the crust was probably formed when individuals descended during ontogeny to mesopelagic and bathypelagic environments. Such structures also form on other species of Globorotalia, such as G. inflata.

Cores 21, 20; Globorotalia praemenardii, Globorotalia miozea, Globorotalia magnifica Assemblages (Plate 7, Figures 3-8)

Most of the taxa are thick-walled forms with great variability. Plate 7, Figure 5 shows a thick-walled $G$. praemenardii; Plate 7, Figure 6 shows a thick-walled G. magnifica. Plate 7, Figures 7, 8 show unidentified specimens.

In Core 20, Section 1, some limbate sutures are present on the spiral side of G. praemenardii (Plate 7, Figure 4). Figure 3 of Plate 7 illustrates a small specimen which still has the unperforated band on the periphery of the umbilical side; the penultimate chamber is of Type A.

Core 19, Section 5; Occurrence of a Raised Keel on the Spiral Side (Plate 7, Figures 1, 2; Plate 8, Figures 5-7)

A new characteristic is observed with the development of a raised keel on the spiral side (Plate 8, Figures 5,7). Limbate sutures are more developed on the spiral side (compare Plate 8, Figure 5 and Plate 7, Figure 4). Plate 7, Figures 1, 2, and Plate 8, Figure 6 illustrate thick-walled G. magnifica.
Core 16; First Occurrence of Globorotalia Type C (Plate 8, Figures 1-4; Plate 9)

The first occurrence of Globorotalia Type C was recognized in Core 16, Section 5 (Plate 8, Figure 2). The rounded specimen illustrated in Plate 8 , Figure 1 is very similar to $G$. lenguaensis, with an imperforated band on the peripheral margin. We note that the specimen illustrated in Plate 5, Figure 1, b, c, has an imperforated band on the three first chambers of the last whorl, on the umbilical side. On Globorotalia Type $\mathrm{C}$ this band is on the peripheral margin (Plate 8, Figure $1 \mathrm{~b}$ ).

Plate 8 , Figure 3 is an unidentified specimen which belongs to the Type B. Plate 8 , Figure 4 shows a penultimate chamber of Type $\mathrm{C}$.

The last occurrence of G. magnifica appears in Core 16 (Plate 9, Figure 5). The specimens shown in Plate 9 , Figures 2, 3, belong to the G. praemenardii group. A raised keel is observed on the last chamber of the specimen illustrated on Figure 3a. Figure 2a has only an imperforated margin. On thick-walled specimens, the occurrence of a keel is seen on the penultimate chamber on the umbilical side (Plate 9, Figure 1c). Plate 9, Figure 4, shows a thick-walled specimen with a penultimate chamber of Type C. Some small and unidentifiable thick-walled morphotypes are illustrated in Plate 9, Figures 6 and 7.

Core 14, Section 5; Thick-walled Specimens-Types $B$ and C (Plate 10, Figures 4-6)

Thick-walled specimens belong to Type B (Figure $4 a$ ) or to Type C (Figure 5a). A keel is present on the spiral side (Plate 10, Figures $4 \mathrm{a}, 5 \mathrm{a}$ ) and also occurs on some chambers on the umbilical side (Plate 10, Figure $4 \mathrm{c})$. The earlier stages are ornamented with spine bases (Plate 10, Figure 6a).

Core 10, Core 9, Section 4; Globorotalia menardii Group 3-Occurrence of a Distinct Keel on the Umbilical Side of Thin-walled Specimens (Plate 10, Figures 1-3; Plates 11, 12)

In these samples, a keel is distinct on the umbilical and on the spiral sides of thin-walled morphotypes (Plate 10, Figure 1). This specimen was identified as Globorotalia menardii sp. 3 (Zachariasse, 1975, pl. 1, fig. 1). Some specimens illustrated have 5-1/2 chambers on the last whorl and show distinct spiral and septal limbate sutures (Plate 10, Figure 3). Other specimens have a depressed spiral suture (Plate 10, Figure 2).

Specimens illustrated in Plate 11 have a great variability. Figures 2 and 3 belong to the Globorotalia menardii Group 3 Tjalsma and Zachariasse, with a limbate (Figure 2) or a depressed spiral suture (Figure 3 ). Figures 1, 4, 5 are thick-walled specimens with or without a keel.

Specimens illustrated on Plate 12 belong to the Globorotalia menardii Group 3 (Figures 1, 2, 3). Plate 12, Figure 3 shows a thick-walled specimen with a raised keel on the last chamber. The specimens illus- 
trated in Plate 12, Figures 4-6 look very primitive with penultimate chambers of Type A (Figure $4 \mathrm{a}$ ) and of Type B (Figures 5, 6).

\section{Core 9, Sections 1, 2; Reduced Planktonic Assemblages}

Some rare morphotypes of the Globorotalia menardii Group 4 Zachariasse were recognized in Core 9, Section 1 in the Globorotalia acostaensis Zone (Tortonian). These specimens are not included in our study because we found only two of them. Because of the limited nature of the planktonic foraminiferal assemblages in Core 9, Sections 1 and 2 (to below the Ammonia tepida assemblages; Wright, this volume) and the presence of numerous reworked specimens (Bizon et al., Range Charts, this volume), we cannot assign a precise age to this part of the section but it is not older than the Globorotalia acostaensis Zone.

In Core 9, Sections 3 and 4, some small, thickwalled specimens were found which may belong to the Globorotalia conomiozea group (or to the G. miozea conoidea group). In Core 9, Sections 1 and 2, the absence of the species Globorotalia humerosa, Globigerinoides obliquus extremus, and Globorotalia mediterranea, which were found in the nearby piston core Fom69 (Bizon et al., 1976) and are generally well known in the late Miocene of southern Spain (Bizon et al., 1975) and Italy (d'Onofrio et al., 1975), suggests that this level is probably older than Messinian.

The 127-cm-thick sequence of submillimetric nannofossil marl laminations (Core 9, Sections 1 and 2) is Messinian in age (Cita et al., this volume). Laminated marls are not restricted to the late Miocene; the same type of sediment has been found in the Valenzuela formation of the Guadalquivir Basin (Tjalsma, 1971) and it occurs in the Burdigalian-Tortonian; laminated marls have also been described by Verdenius (1970) in the Chaves formation (Langhian to Tortonian).

The rare presence of Ceratolithus cf. tricorniculatus in Samples 9-1, $115 \mathrm{~cm}, 9-2,23 \mathrm{~cm}$, and 9-2, $49 \mathrm{~cm}$ (Müller, this volume) is the only micropaleontological evidence for their late Tortonian-early Messinian age, if it is accepted that these specimens are in place and indeed are true $C$. tricorniculatus.

The existence of a hiatus corresponding to at least the entire Tortonian ( 13 to $\mathrm{N} \mathrm{17)} \mathrm{(Cita,} \mathrm{this} \mathrm{vol-}$ ume) between Samples 9-2, $50 \mathrm{~cm}$ and $9-2,110 \mathrm{~cm}$ is disputed by the present authors. We recognize the presence of N 15 from Sample 10-2, $100 \mathrm{~cm}$ to Sample $9-3,20 \mathrm{~cm}$, and $\mathrm{N} 16$ from Sample 9-2, $110 \mathrm{~cm}$ to Sample 9-1, $96 \mathrm{~cm}$. Because the hiatus is also not apparent to the sedimentologists (See Mélières, X-ray mineralogy detailed studies of Core 9, Sections 1 and 2 , Hole 372 , this volume), and because the planktonic foraminiferal assemblages indicate some reduction of the water depth below the shallow-water evaporite deposits, with a very few Orbulina in Sample 9-2, 75 $\mathrm{cm}$, below the Ammonia tepida assemblages, we conclude that the hiatus, if it exists at all, occurs below the broken piece of gypsum on the top of Core 9, Section 1, rather than in Section 2.
Ammonia tepida, a lagoonal species, is not normally associated with planktonic foraminifers; either the planktonic foraminiferal assemblages have been displaced into a lagoonal environment, or the Ammonia are displaced. The latter is less probable because we found numerous specimens in all samples from 9-2, 41 $\mathrm{cm}$ to $9-1,96 \mathrm{~cm}$.

In conclusion, exact dating of the sediments in the lower part of Core 9, Section 1, and the upper part of Core 9 , Section 2, is questionable.

\section{SYSTEMATICS}

Family GLOBORATALIIDAE Cushman, 1927

Genus GLOBORATALIA Cushman, 1927

Globorotalia magnifica Bizon and Glaçon n. sp. (Plate 3, Figures 1a-3c)

Holotype: Plate 3, Figures la-c.

Paratypes: Plate 3, Figures 2a-3c.

Type locality: East Menorca Rise, Mediterranean Sea, lat $40^{\circ} 01.86^{\prime} \mathrm{N}$; long $04^{\circ} 47.79^{\prime} \mathrm{E}$.

Type Sample: Deep Sea Drilling Project, Leg 42A, Site 372, Core 23 , Section $5,100 \mathrm{~cm}$.

Type level: Globorotalia fohsi peripheroronda Zone, Langhian.

Depository: Museum of Natural History, Paris, France, no. 472a, b, c.

Description: Large spiroconvex test. Equatorial periphery rounded to oval, very slightly lobulate only in the last two chambers. Axial profile with a subacute peripheral margin, with a distinct keel.

Spiral side-on the last whorl, five chambers become regularly but rapidly larger from the first to the fifth chamber. The spiral suture is slightly limbate or depressed. The septal sutures are rounded between the first chambers, with progressively increasing curvature. The last suture between the penultimate and ultimate chambers is nearly radial at the beginning and strongly recurved at the middle part of the chamber, becoming tangential to the periphery. The last septal sutures are limbate in the holotype.

Umbilical side-the umbilicus is very small; umbilical sutures are sinuous, somewhat incised, depressed. The aperture is a very low arch which is interiomarginal, umbilical, and extraumbilical, with a narrow lip slightly broader toward the umbilicus.

The calcareous wall is smooth, finely perforated in the last whorl; a deposit of secondary laminae obscures the first whorls on the spiral side. On the umbilical side, small pustules have developed on the two first chambers, near the aperture. Coiling is predominantly sinistral.

Dimensions: Maximum diameter of holotype: $0.56 \mathrm{~mm}$.

Compared to the holotype, the specimen illustrated in Plate 3, Figure 2 has septal sutures that are more weakly limbate, and the specimen illustrated in Plate 3, Figure 3 is more flattened. The outline of the chambers, on the spiral side, is similar in the holotype and paratypes.

Remarks: Globorotalia magnifica, n. sp., resembles Globorotalia menardii (d'Orbigny) subspecies panda Jenkins, 1960, described from the Miocene in Australia, in having the same large size and the same convexity of the spiral side. It differs in having a different penultimate chamber outline; the last suture in $G$. menardii panda is rounded, the last suture in G. magnifica is straight, becoming strongly recurved. Umbilical sutures are sinuous in G. magnifica, straight and thickened in G. menardii panda. In the specimens from New Zealand illustrated in 1971 by Jenkins (pl. 6, fig. 152-154), Globorotalia panda is of small size $(0.3 \mathrm{~mm})$ with weakly incurved sutures on the spiral side.

Globorotalia magnifica differs from G. archeomenardii Bolli by its large size and the shape of the spiral chambers: penultimate chamber of $G$. archeomenardii has a rounded forward periphery, whereas the penultimate chamber of $G$. magnifica has a straighter forward periphery. G. magnifica resembles G. praemenardii Cushman and Stainforth in having the same penultimate chamber outline. It differs by the less lobulate equatorial periphery and the sinuous sutures on 
the umbilical side. This species probably evolved from Globorotalia archeomenardii in the upper part of the Globorotalia fohsi peripheroronda Zone.

Stratigraphic range: At Site 372, Core 24, Section 2 to Core 16, Section 5 with a maximum in Core 23, Section 5; Globorotalia fohsi peripheroronda Zone (upper part) to Globorotalia mayeri Zone (lower part) Globorotalia magnifica has been observed in southern Spain in the late Langhian.

At Site 372, the lower occurrence of G. magnifica overlaps the last occurrence of Globorotalia archeomenardii and the first occurrence of $G$. praemenardii. The highest occurrence overlaps the first occurrence of Sphaeroidinellopsis subdehiscens (Sample 16-6, $90 \mathrm{~cm}$ ). The stratigraphic range roughly corresponds to that of Globorotalia fohsi fohsi, G. fohsi lobata and G. fohsi robusta in Trinidad (N 10-N 13, part).

\section{CONCLUSION}

The different biostratigraphic intervals recognized at Site 372 are shown in Figure 3. A combination of the standard zonation (on the right) with the Globorotalia praescitula-Globorotalia menardii lineages leads to finer subdivisions.

Five zones were recognized from Core 31 to Core 9: Praeorbulina glomerosa, Globorotalia fohsi peripheroronda, Globorotalia mayeri, Globorotalia menardii, Globorotalia acostaensis (Bizon, this volume). Six different intervals are specified in this study on the basis of two evolutionary trends (see Figure 3, second column from right):

1) Variation of the penultimate chamber outline with the three successive occurrences of types A, B, and C.

2) Carinal development with the progression of time of: (a) a continuous imperforated band on the umbilical side, near the periphery; (b) a peripheral continuous imperforated band; (c) formation of a distinct keel, somewhat raised on the spiral side; and (d) a distinct keel on the spiral and umbilical sides.

This carinal development appears also to be present in specimens from the Caribbean region, i.e., compare the figures of $G$. praemenardii in Bolli, 1957 ( $G$. fohsi fohsi Zone) and in Blow, 1969 (G. fohsi lobata-robusta Zone) (see also Figure 2). This trend exists in different lineages which are "chronologically and biologically separated" (Stainforth et al., 1975) and is reiterated within them (keeled specimens are already present in G. magnifica as in G. archeomenardii holotype) (see Figure 2). On one lineage, carinal development is regarded as a better identifying criterion than the limbation on the spiral side, occurs in many specimens throughout our material.

The ontogeny of some morphotypes follows the phylogenetic trends. Thick-walled morphotypes are probably bathypelagic. The same evolutionary trends were observed for the thick-walled morphotypes and the thin-walled morphotypes. Some associations of thin-walled and thick-walled specimens from the Southwest Pacific (Leg 21, Site 208, North Lord Howe Rise) were described by Kennett (1973).

The great variability of the planktonic foraminiferal assemblages in Site 372 from one core to another is probably temperature-related and is similar to the "inimical environment" described by Stainforth et al. (1975). These initial investigations allow reasonably good correlations to be made with southern Spain and Crete. The trends are not endemic to the Mediterranean and have been observed on the Atlantic side (Guadalquivir area). Correlations with tropical zonation are possible for some intervals.

\section{ACKNOWLEDGMENTS}

The writers wish to thank Dr. Beckmann, Dr. Berggren, and Dr. Tjalsma who reviewed the manuscript. They are grateful also to Dr. H. Bolli, Dr. J. Raiga-Clemenceau, and J. J. Bizon for their comments. Dr. W. J. Zachariasse provided us with specimens of Globorotalia menardii from Crete. We are grateful to Dr. Tintant, Dr. Rat, and Mr. Bert (University of Dijon), to Mrs. Guillaume and André (University of Paris VI) for scanning electron microscope facilities. Mrs. C. Barres assisted the authors in the laboratory work; A. Magné prepared the photographs.

\section{REFERENCES}

Bé, A. W. H. and Hemleben, C., 1970. Calcification in a living planktonic foraminifer, Globigerinoides sacculifer (Brady): N. Jb. Geol. Paläont. Abh., v. 134, p. 221-234.

Berggren, W. A., 1971. Multiple phylogenetic zonations of the Cenozoic based on planktonic foraminifera: Second Plankt. Conf. Proc., v. 1, p. 41-56.

Berggren, W. A. and Van Couvering, J. A., 1974. The late Neogene: Palaeogeogr., Palaeoclimatol., Palaeoecol., v. 16 , p. 1-216.

Bizon, G., Bizon, J. J., and Mauffret, A., 1975. Présence de Miocène terminal et de Pliocène inférieur au large de Minorque (Baléares, Espagne): Rev. I.F.P., v. 30, p. 713727.

Bizon, G., Bizon, J. J., and Montenat, C., 1972. Le Miocène terminal dans le levant espagnol (provinces d'Alicante et de Murcia): Rev. I.F.P., v. 27, p. 831-862.

1976. Définition biostratigraphique du Messinien: C. R. Acad. Sci. Paris, v. 281, p. 359-362.

Blow, W. H., 1969. Late middle Eocene to Recent planktonic biostratigraphy: First Intern. Conf. Plank. Microfossils, Proc., v. 1, p. 199-422.

Bolli, H. M., 1957. Planktonic foraminifera from the Oligocene Miocene Cipero and Lengua formations of Trinidad, B.W.I.: U.S. Nat. Mus. Bull. 215, p. 97-124.

1966. The planktonic foraminifera in well Bodjonegoro 1 of Java: Ecolog. Geol. Helv., v. 59, p. 449-465.

Bronnimann, P., 1971. A Neogene Globigerinacean biochronologic time scale of the Southernwestern Pacific. In Winterer, E. L., Riedel, W. R., et al. Initial Reports of the Deep Sea Drilling Project, Volume 7: Washington (U.S. Government Printing Office), p. 1235-1469.

Cati, F. and Borsetti, A. M., 1968. Biostratigrafia del Miocene in facies romagnola (formazione marnoso-arenacëa. Giorn. Geol., v. 35, p. 401-410.

Cati, F. et al., 1968. Biostratigrafia del Neogene mediterranea basata sui foraminiferi planctonici: Boll. Soc. Geol. Ital., v. 87, p. 491-503.

Cita, M. B., Premoli-Silva, I., and Rossi, R., 1965. Foraminiferi planctonici del Tortoniano-tipo: Riv. Ital. Paleontol., v. 71 , p. $217-308$.

Cita, M. B. and Blow, W. H., 1969. The biostratigraphy of the Langhian, Serravallian and Tortonian stages in the typesections in Italy: Riv. Ital. Paleontol., v. 75, p. 549603.

Crescenti, U., 1966. Sulla biostratigrafia del Miocene affiorante al confine marchiano-abruzzese: Geol. Romana, v. 5, p. 1-54. 
Jenkins, D. G., 1960. Planktonic foraminifera from the Lakes Entrance oil shaft, Victoria, Australia: Micropaleontology, v. 6, p. $345-371$.

1971. New Zealand Cenozoic planktonic foraminifera: New Zealand Geol. Surv. Paleontol. Bull., v. 42, p. 1-278.

Kennett, J. P., 1973. Middle and late Cenozoic planktonic foraminifera biostratigraphy of the South-West Pacific: In Beuns, R. E., Andrews, J. E., et al., Initial Reports of the Deep Sea Drilling Project, Volume 21: Washington (U.S. Government Printing Office), p. 575-639.

Olsson, R. K., 1971. The logarithmic spire in planktonic foraminifera: its use in taxonomy, evolution and palaeoecology: Gulf Coast Assoc. Geol.. Soc. Trans., v. 21, p. 419432.

Onofrio, S. d' et al., 1975. Planktonic foraminifera of the upper Miocene from some Italian sections and the problem of the lower boundary of the Messinian: Soc. Paleontol. Ital. Bull., v. 14, p. 177-196.

Parker, F. L., 1973. Late Cenezoic biostratigraphy (planktonic foraminifers) of tropical Atlantic deep-sea sections: Rev. Esp. Micropol., v. 5, p. 253-290.

Ryan, W. B. F., et al., 1974. A paleomagnetic assignment of Neogene stage boundaries and the development of isochronous datum planes between the Mediterranean, the Pacific and Indian Oceans in order to investigate the response of the world Ocean to the Mediterranean "salinity crisis;'’ Riv. Ital. Paleontol., v. 80, p. 631-688.
Saito, T. and Maiya, S., 1973. Planktonic foraminifera of the Nishikurosawa formation, Northeast Honshu, Japan: Proc. Paleontol. Soc. Japan, Trans. n.s., v. 91, p. 113-125.

Scott, G. H., 1972. The relationship between Miocene foraminiferida Globorotalia miozea miozea and $G$. praemenardii: Micropaleontology, v. 18, p. 81-93.

Stainforth, R. M. et al., 1975. Cenozoic planktonic foraminiferal zonation and characteristics of index forms: Univ. Kansas, Paleontol. Contrib., v. 62, p. 1-425.

Tjalsma, R. C., 1971. Stratigraphy and foraminifera of the Neogene of the eastern Guadalquivir Basin (Southern Spain): Utrecht Micropal. Bull., v. 4, p. 1-161.

Verdenius, J. G., 1970. Neogene stratigraphy of the western Guadalquivir Basin (Southern Spain): Utrecht Micropal. Bull., v. 3, p. 1-109.

Zachariasse, W. J., 1975. Planktonic foraminiferal biostratigraphy of the late Neogene of Crete (Greece): Utrecht Micropal. Bull., v. 11, p. 1-171.

\section{EXPLANATION OF PLATES}

On the following plates, size bars represent $50 \mu \mathrm{m}$; $\mathrm{a}, \mathrm{b}, \mathrm{c}$, are, respectively, spiral, lateral, and umbilical views for a single specimen. Plate explanations are included in the text. 
PLATE 1

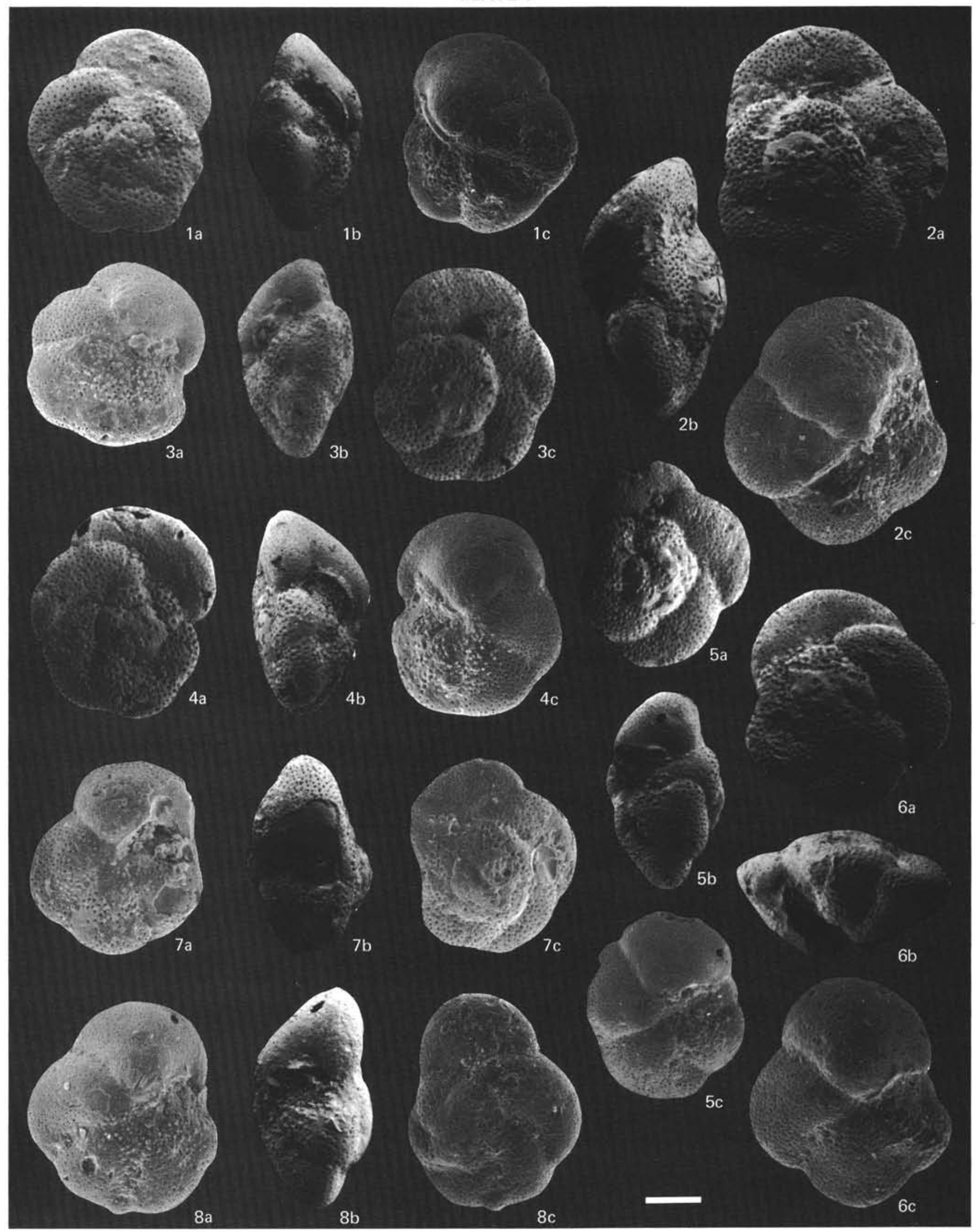

Globorotalia scitula praescitula assemblages. Penultimate chamber type A. Sample 31-2, $100 \mathrm{~cm}$. 
PLATE 2

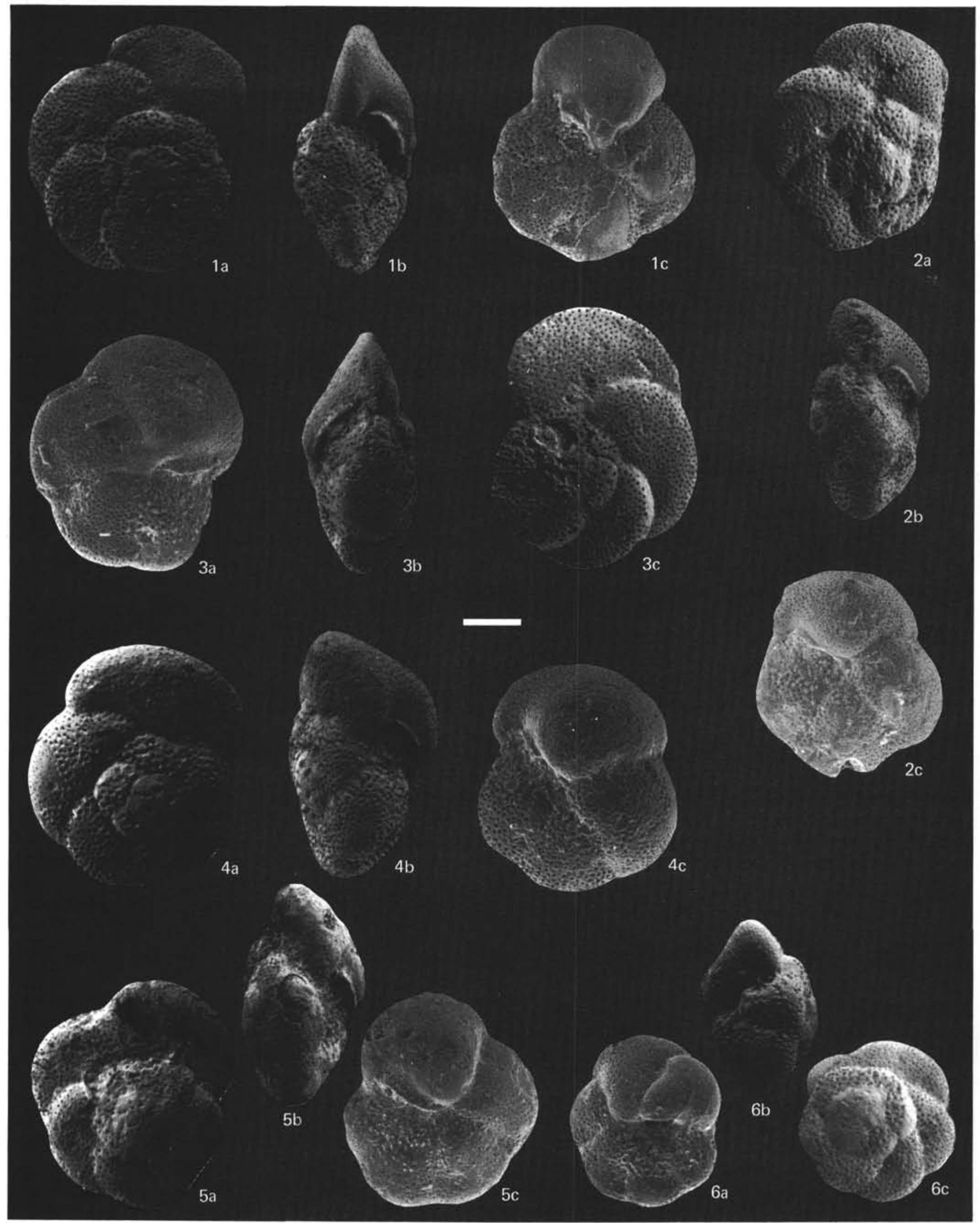

Globorotalia scitula praescitula assemblages. Penultimate chamber type A - angular peripheral margin $(1,3)$. -Figures 5-6 


\section{PLATE 3}
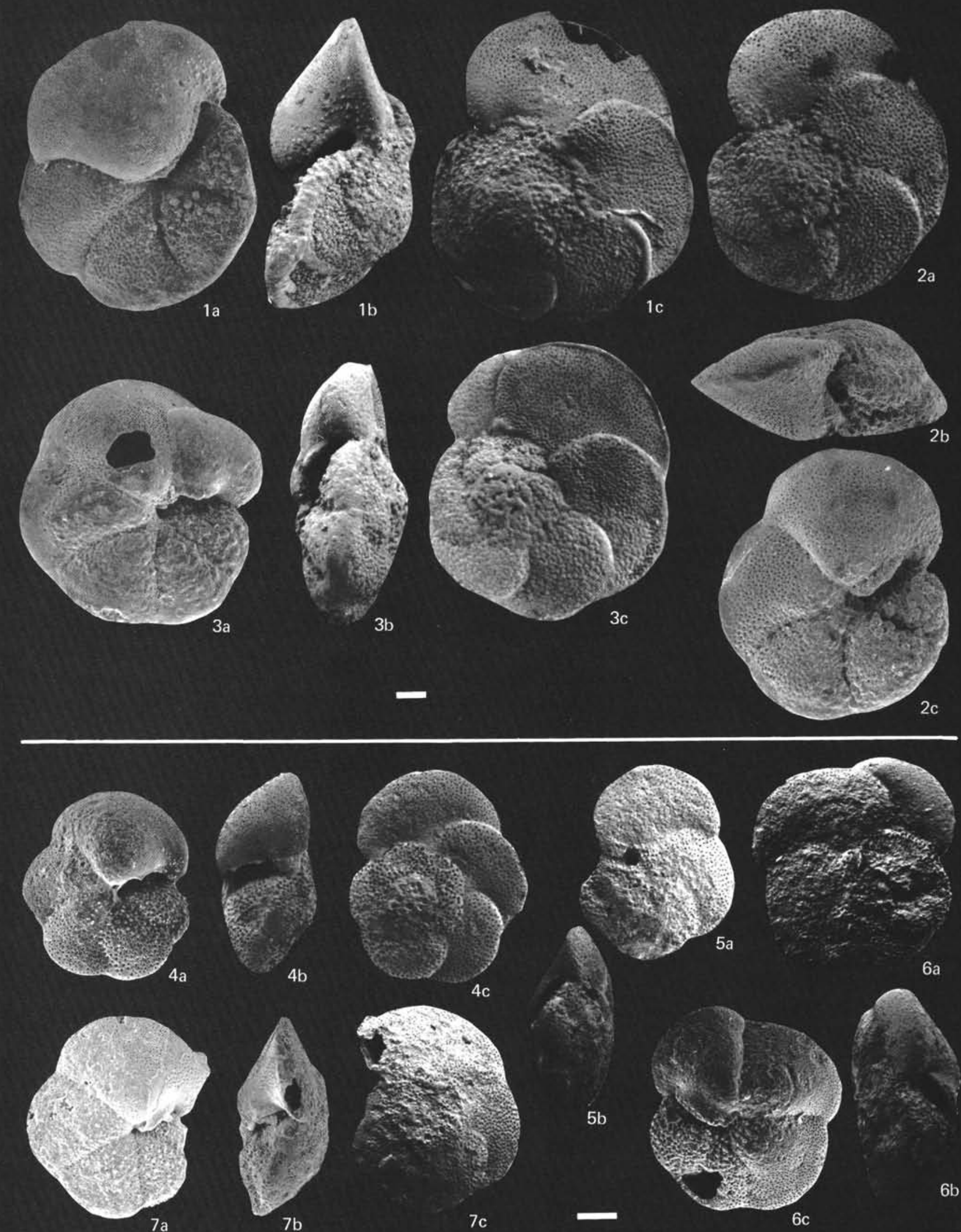

Figure 1

Figures 2, 3 Figures 4-7
Holotype.

Globorotalia magnifica n. sp.

Paratypes. Sample 23-5, $100 \mathrm{~cm}$. 
PLATE 4

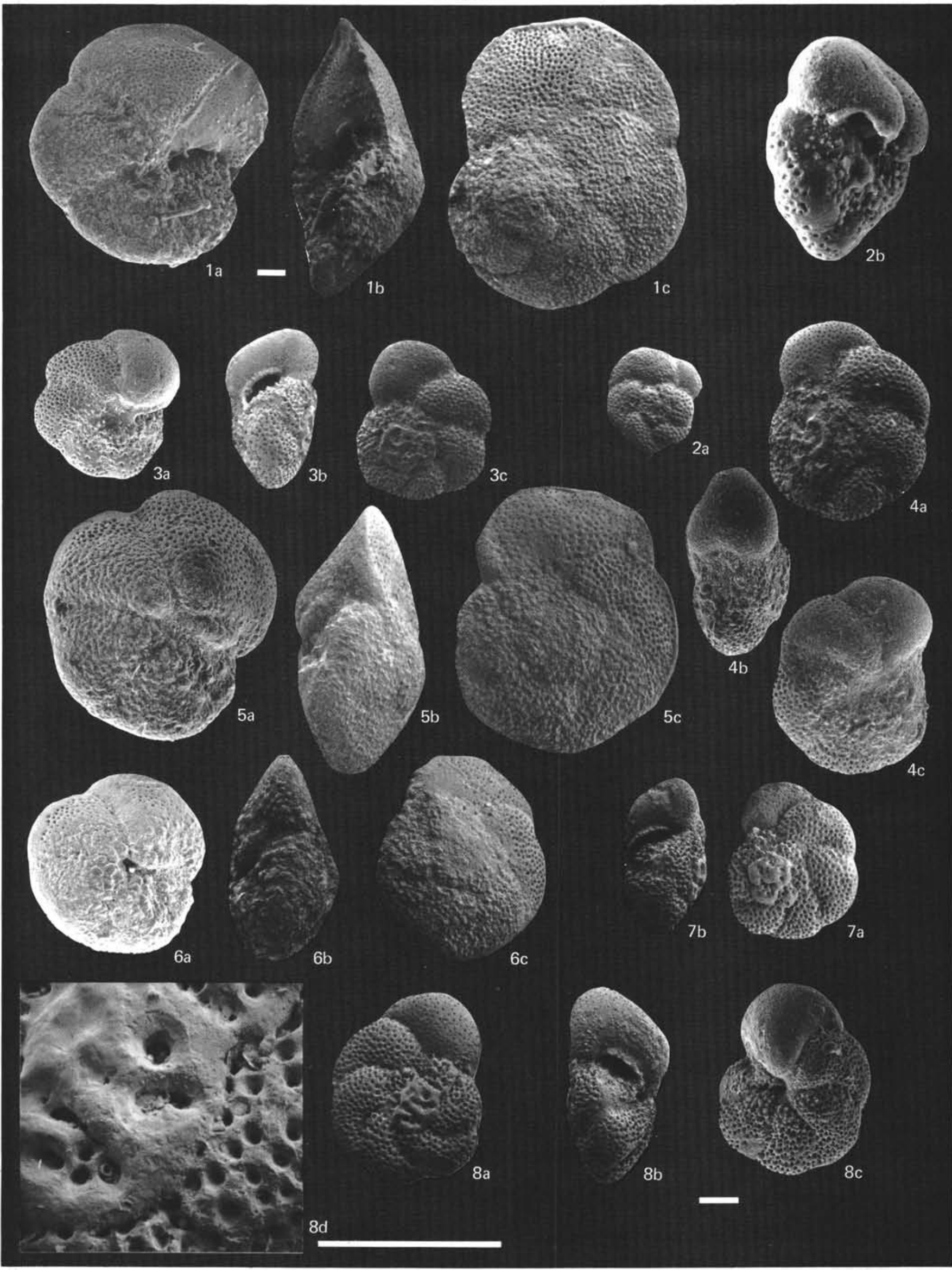

Figures 1 to 5 Figures 6 to 8
Core 23-4, $100 \mathrm{~cm}$. 1, 5:G. magnifica n. sp., thickwalled form. 3, 4: G. fohsi peripheroronda. Core 23-5, $100 \mathrm{~cm}$. 6: G. miozea. 7, 8: G. fohsi peripheroronda. 


\section{PLATE 5}
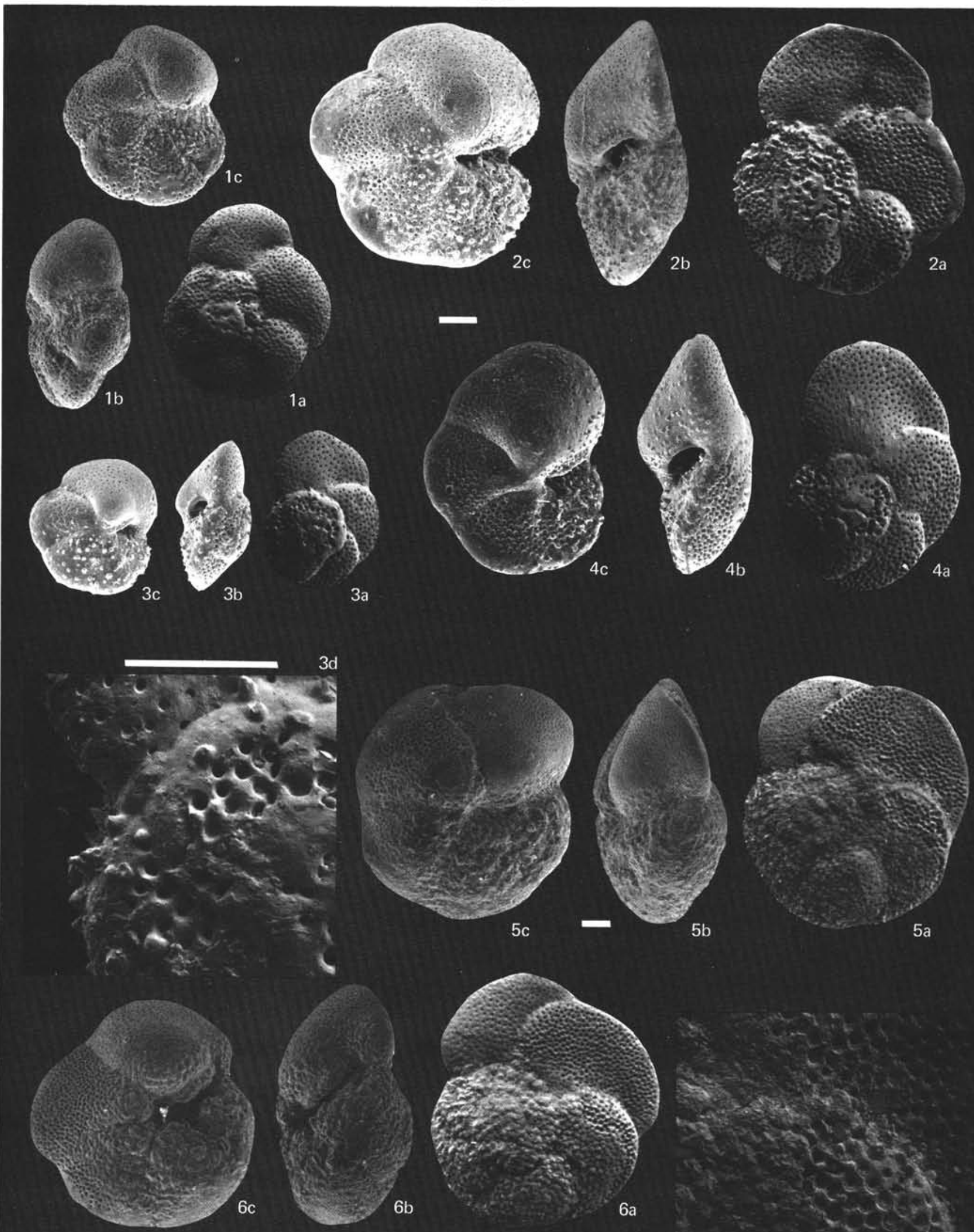

$6 d$

Figures 1 to 5 . Figure 6
Sample 23-1, $140 \mathrm{~cm}$. (2: G. praemenardii.)

Sample 23-2, $100 \mathrm{~cm}$. (thick-walled form type B without keel). 
PLATE 6

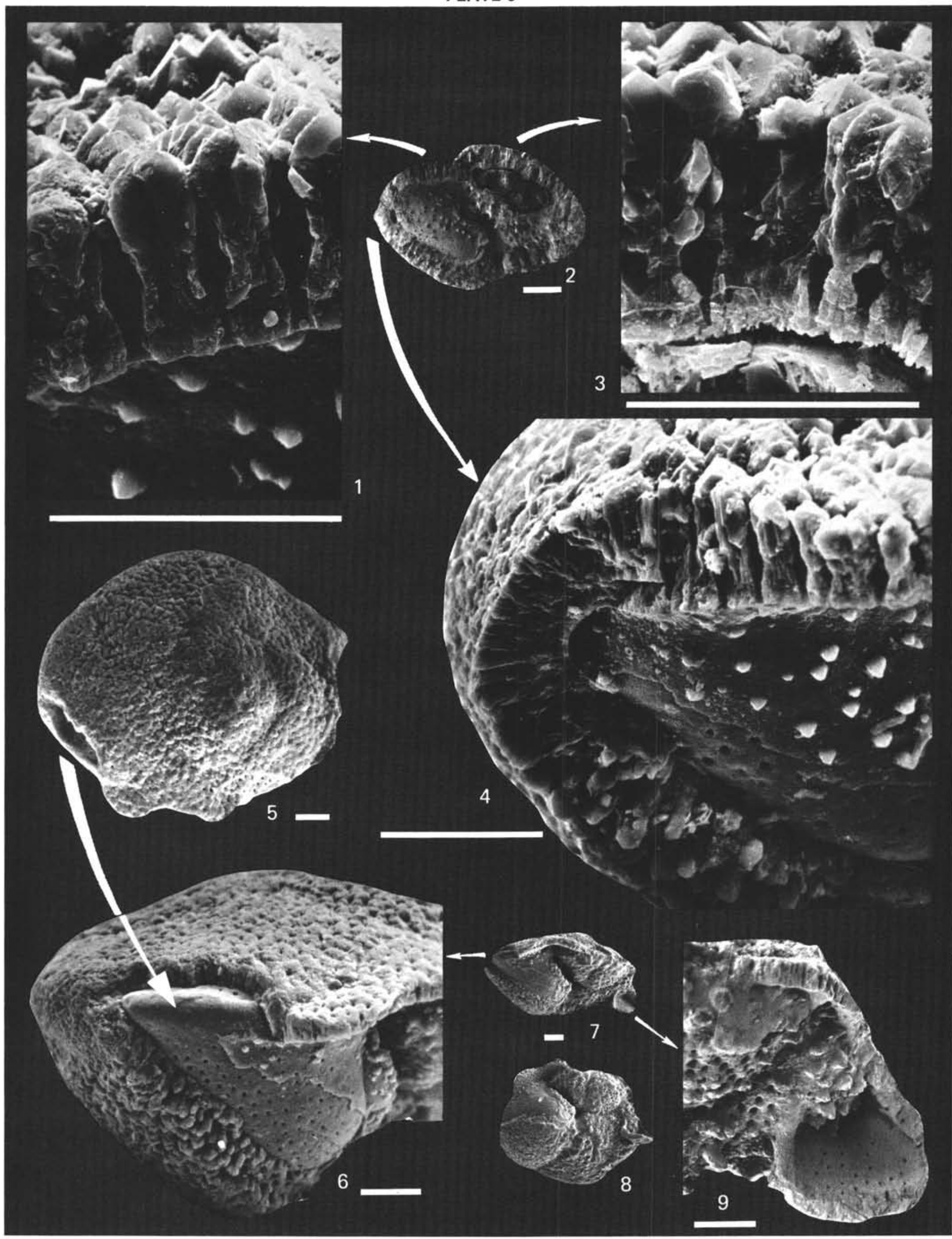

Thick-walled forms.

Figures 1-4 Sample 21-3, $100 \mathrm{~cm}$. Figures 5-9 Sample 21-4, $100 \mathrm{~cm}$. 


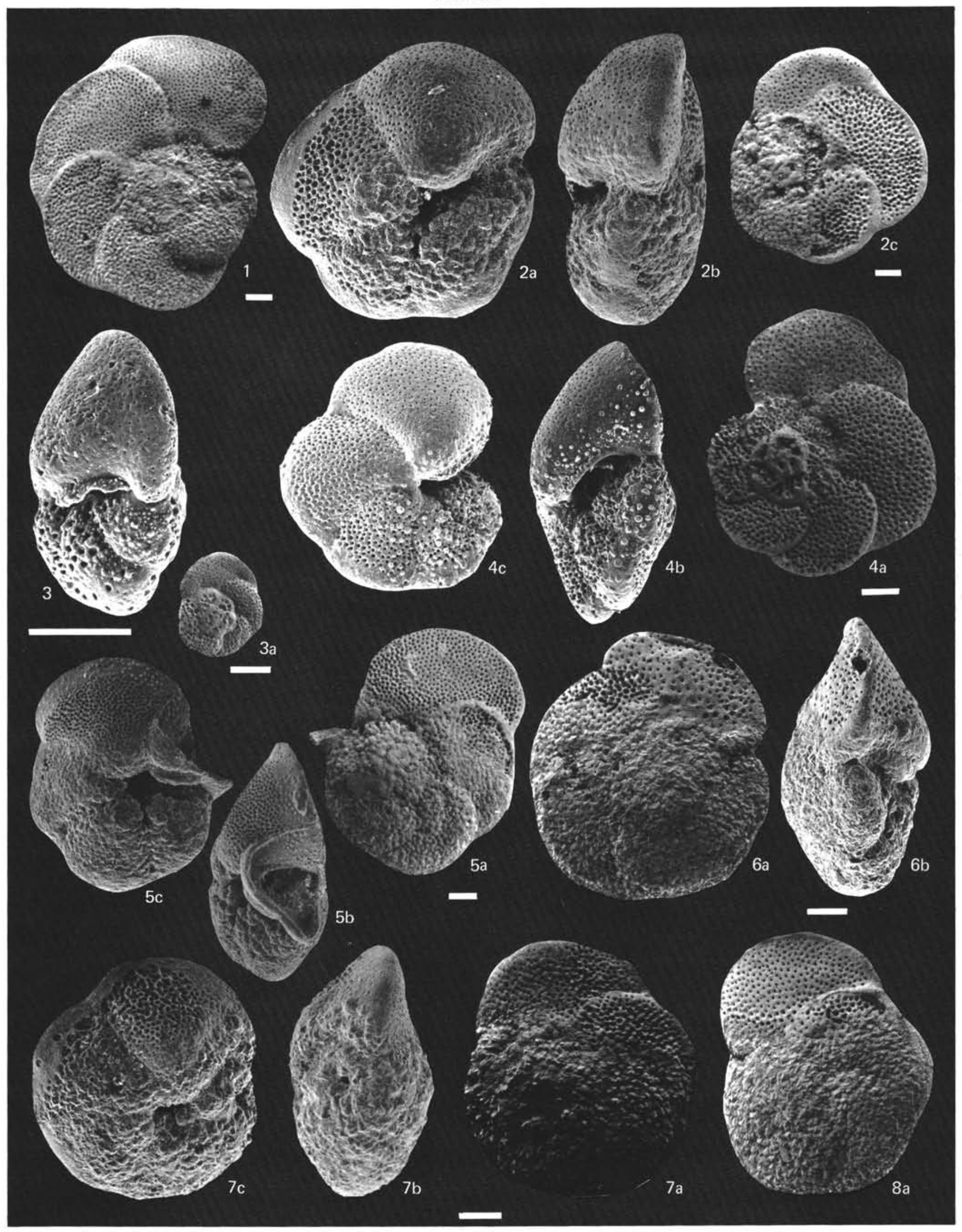

Figures 1, 2

Figures 3, 4
Globorotalia praemenardii $-G$ miozea assemblages.
Sample 19-5, $100 \mathrm{~cm}$.
Figures 5, 6, 8
Sample 21-4, $100 \mathrm{~cm}$.
Sample 20-1, $100 \mathrm{~cm}$.
Figure 7
Sample 23-1, $140 \mathrm{~cm}$. 
PLATE 8

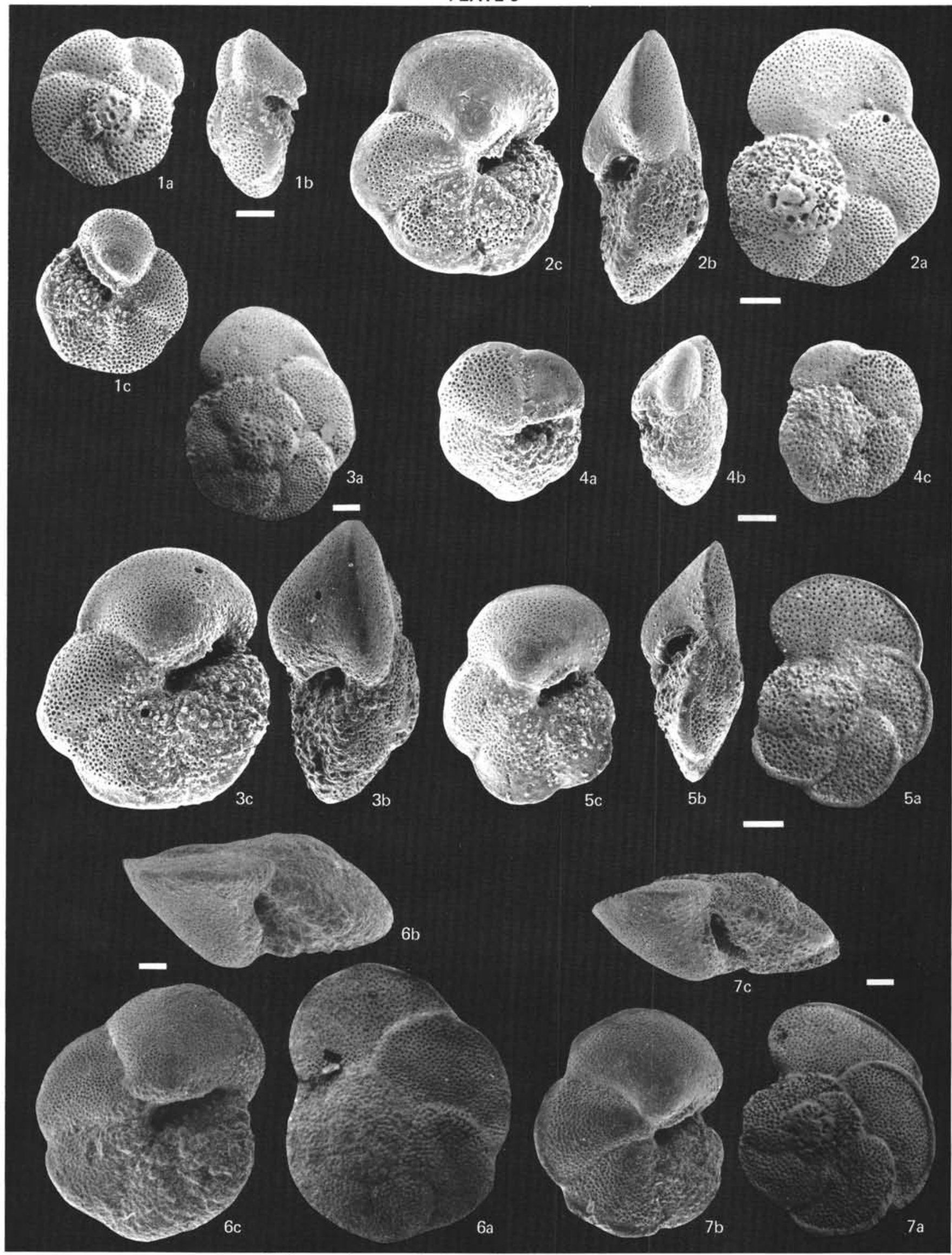

Globorotalia type C. Assemblages of Cores 16 and 19.

Figures 1-4

Sample 16-5, $100 \mathrm{~cm}$.

Figures 5-7

Sample 19-5, $100 \mathrm{~cm}$. 


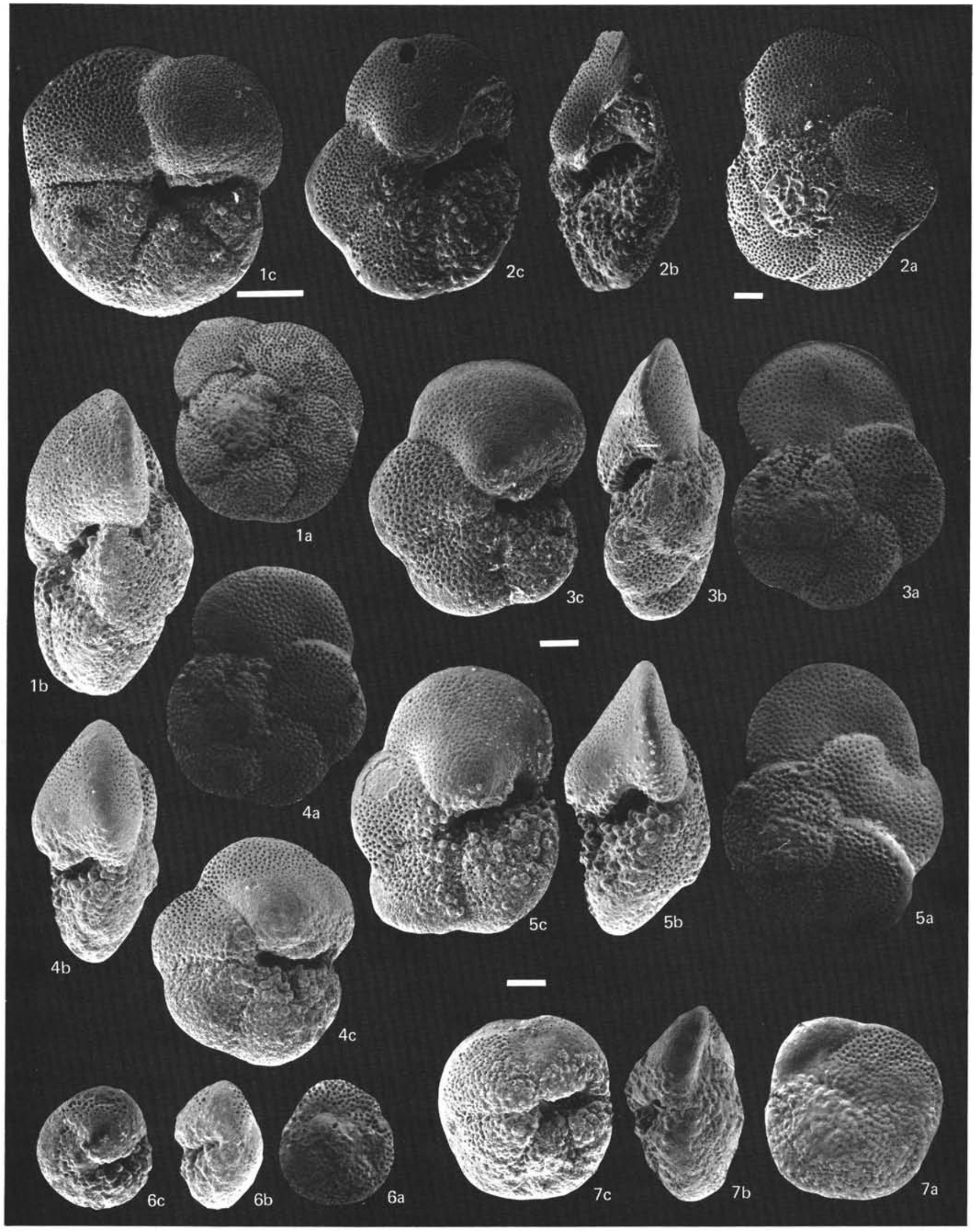

Assemblages of Core 16 .

Figure 1

Figures 2-5

Figures 6, 7
Sample 16-2, $100 \mathrm{~cm}$

Sample 16-3, $90 \mathrm{~cm}$.

Sample 16-4, $100 \mathrm{~cm}$. 


\section{PLATE 10}

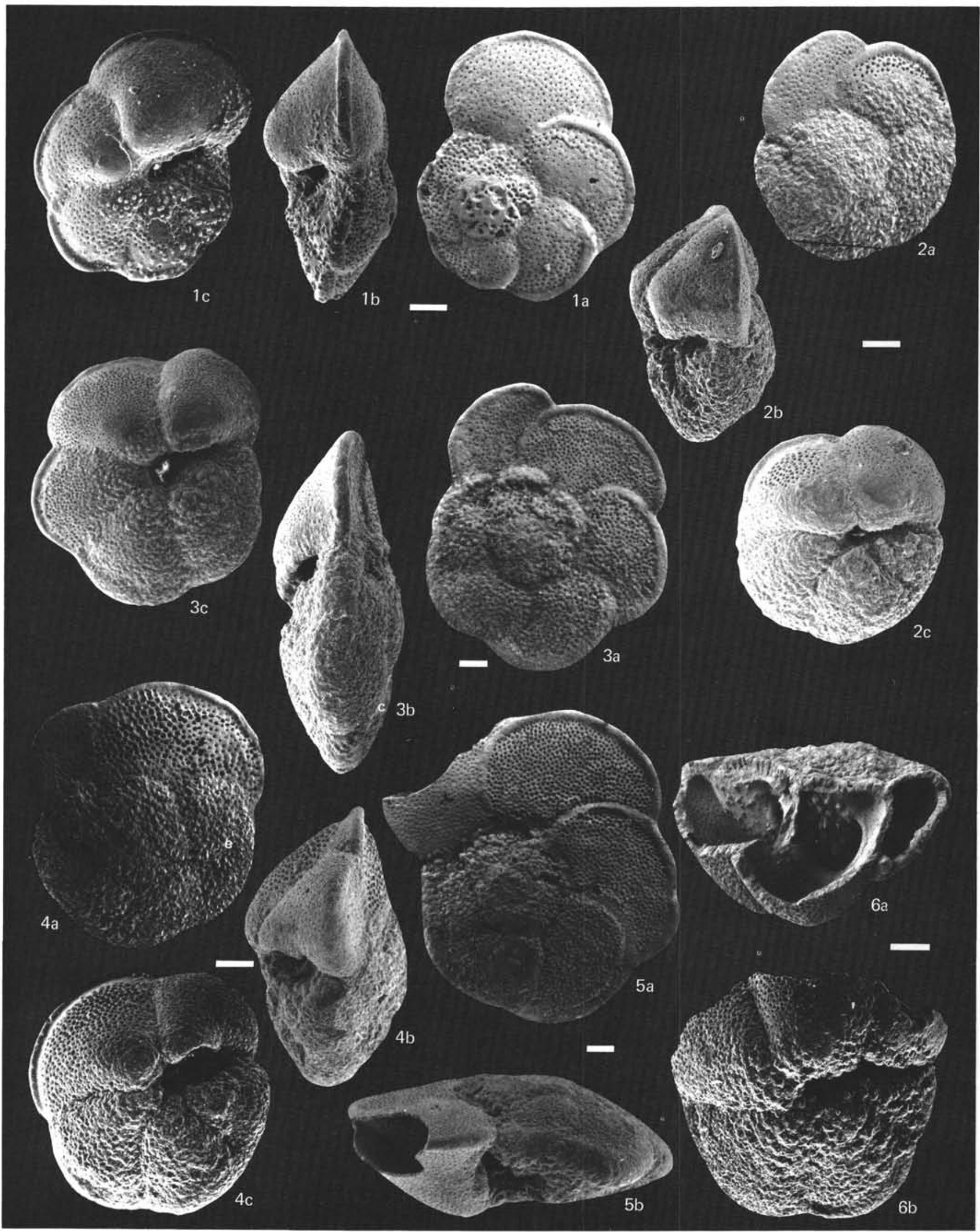

Assemblages of Cores 10 and 14.

Figures 1-3

Sample 10-2, $5 \mathrm{~cm}$. G. menardii group 3 T. \& Z.

Figures 4-6

Sample 14-5, $100 \mathrm{~cm}$. Thick-walled forms. 


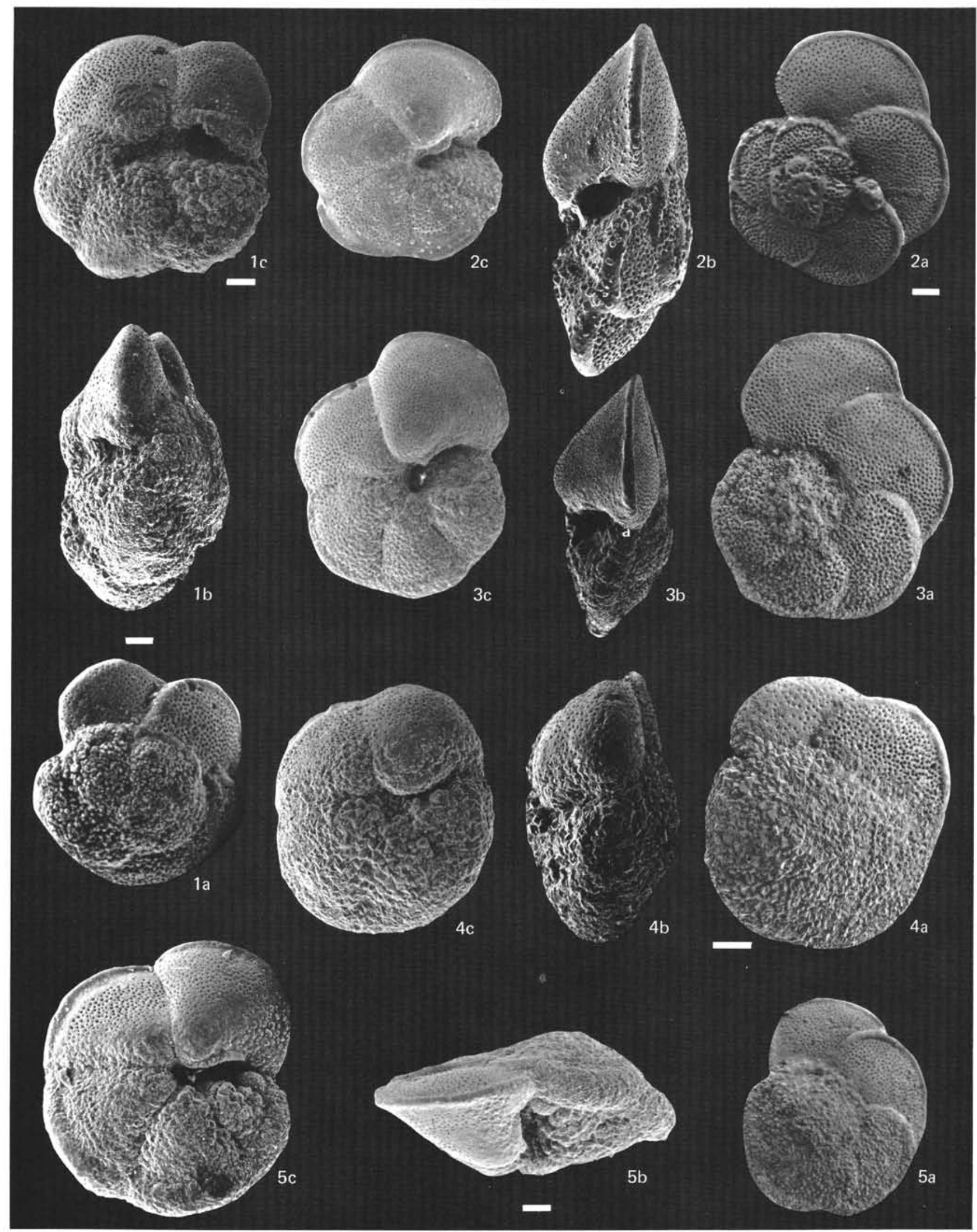

Keel, limbate sutures in thin- and thick-walled forms.

Figures 1-4

Sample 10-1, $120 \mathrm{~cm}$.

Figure 5

Sample 10-2, $5 \mathrm{~cm}$. 
PLATE 12
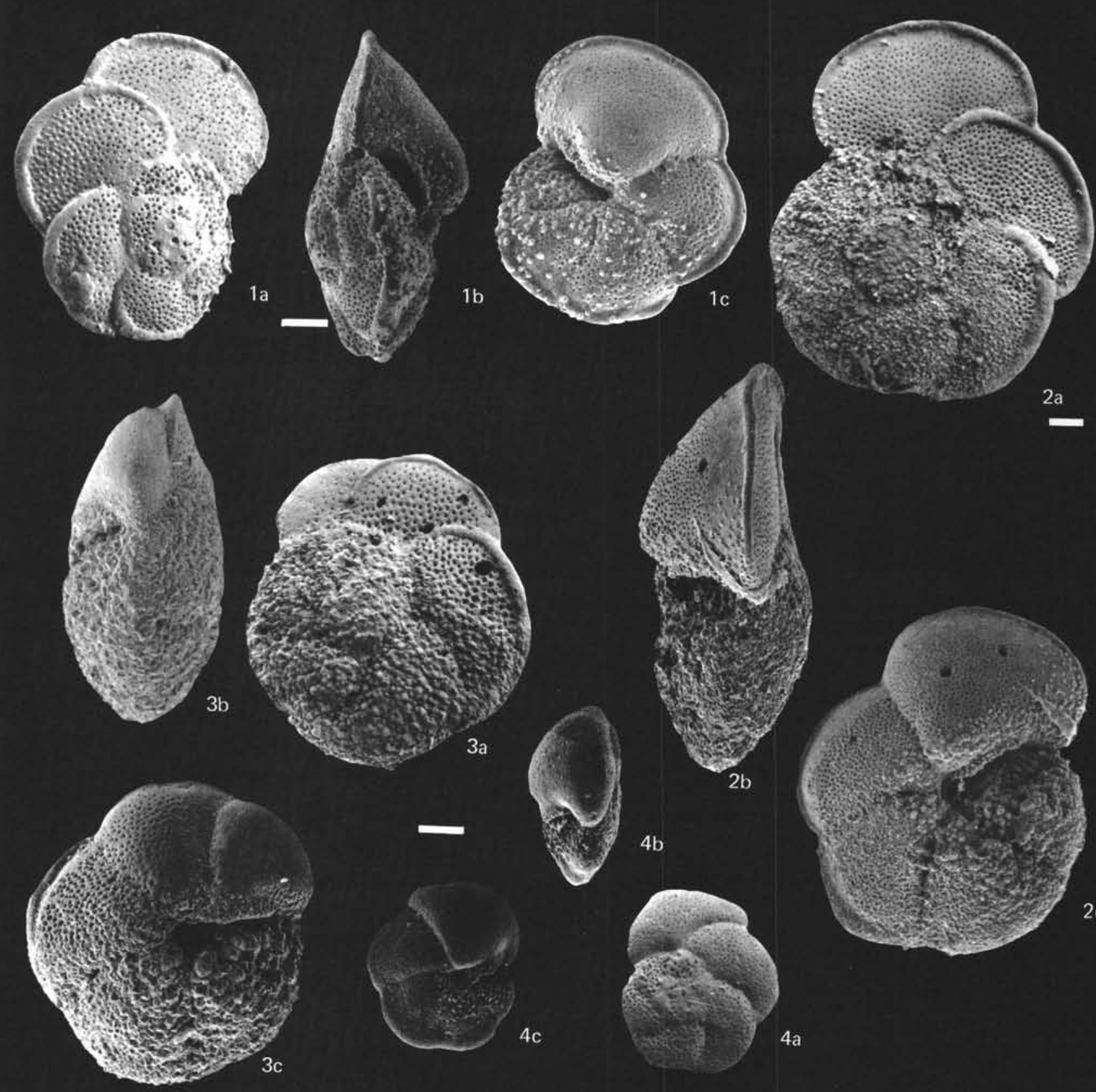

$2 c$
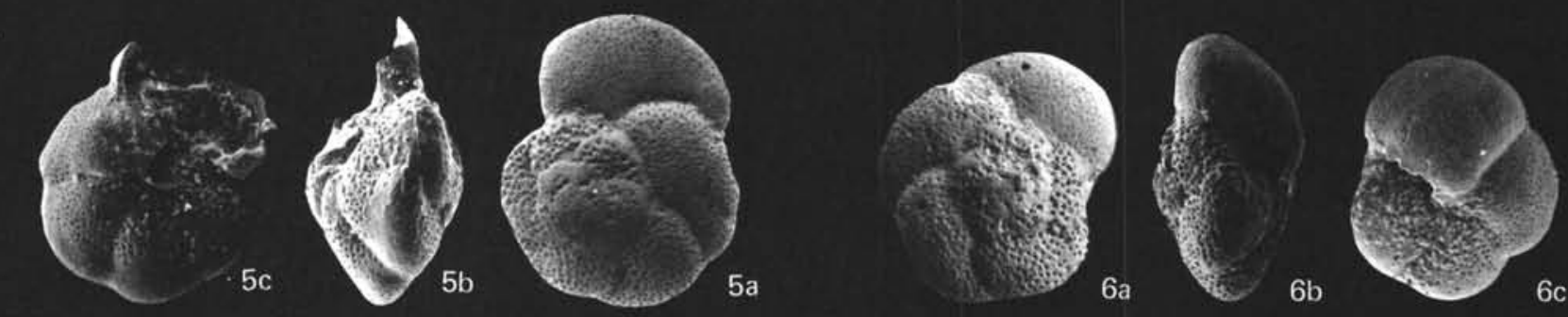

Assemblages of Cores 9 and 10 .

Figures $1-4$

Sample 9-4, $100 \mathrm{~cm}$.

Figures 5, 6

Sample 10-1, $120 \mathrm{~cm}$. 